\title{
Economic Traits and Performance of Italian Quails Reared at Different Cage Stocking Densities
}

- Author(s)
Faitarone $A B G^{* 1}$
Pavan $A C^{2}$
Mori $C^{2}$
Batista $L S^{2}$
Oliveira RP2
Garcia EA
Pizzolante CC
Mendes $A A^{3}$
Sherer MR
1 Postgraduate, Animal Science - FMVZ/
UNESP
2 Graduate Student, Animal Science - FMVZ/
UNESP
3 Teacher, Departament of Animal Production
- FMVZ/UNESP
4 Researcher, APTA, Unit of Research and
Development of Brotas
5 Animal Scientist, Departament of Animal
Production - FMVZ/UNESP. Botucatu, SP,
Brazil

Mail Address

Edivaldo Antonio Garcia

Faculdade de Medicina Veterinária e

Zootecnia, UNESP

CP 560

Distrito de Rubião Junior

18.690-1000. Botucatu, SP, Brazil

E-mail: egarcia@fca.unesp.br

\section{Keywords}

cage stocking density, economic traits, Italian quail, performance.

\section{ABSTRACT}

This study assessed the effect of different cage stocking densities on the performance of Italian quails in the laying period. Two hundred and sixty four quails with 30 weeks of age and $280 \mathrm{~g}$ mean body weight were used. Birds were randomly assigned to $96 \times 33 \times 16 \mathrm{~cm}$ cages and distributed in a randomized block design with 4 treatments $(12,15,18$ and 21 quails per cage or 264, 211, 176 and $151 \mathrm{~cm}^{2}$ per quail, respectively) and 4 replicates. Birds were given feed and water ad libitum and submitted to the same experimental conditions. The experimental diet was formulated based on NRC (1994) recommendations. There were no significant differences among treatments for feed conversion per egg mass $(\mathrm{kg}: \mathrm{kg})$, percentage of broken eggs and mortality. There was a linear reduction $(p<0.05)$ in egg weight, feed consumption, percentage of production, egg mass and feed conversion per dozen with the increase in stocking density. The gain per house per day was better at the cage density of $151 \mathrm{~cm}^{2}$ per bird. However, the density of $211 \mathrm{~cm}^{2}$ per bird provided the best gain per bird per day, because this stocking density had better productive indexes when compared with the other treatments.

\section{INTRODUCTION}

There is an increasing need of protein of animal origin intended for human consumption, including meat and eggs. Therefore, farmers and researchers constantly search for new approaches to animal production and husbandry practices in order to improve the productivity indexes of the Brazilian agriculture and livestock production.

Quail production is a good alternative to animal protein production, because housing costs are not so high, and quails have smaller body weight and space requirements are small. Besides, less waste is produced compared with other conventional livestock enterprises, and thus it is not so detrimental to the environment.

In Brazil, quail production is focused on egg production. Quail meat production, on the other hand, is most of the times unsystematic and empiric because there are no genetic stocks, and there is scarce data on feed intake, carcass yield and ideal weight at slaughter.

The egg industry have increasingly used high stocking densities for laying hens and quails both during the rearing and laying phases as a means to decrease housing and equipment costs per bird. Nevertheless, the excessive reduction in the available cage area per bird, as well as feeder and drinker space per bird, may have negative effects on growth and later performance, since feed intake might decrease and, consequently, live weight, and muscular and bone development (Anderson \& Adams, 1992). Body weight and feed intake are crucial factors in bird development, egg production, egg size and feed conversion. 
Stocking density has become a highly important economic factor due to the intensification of industrial poultry production, which resulted in decreased gain per bird housed and too small profit margins. Therefore, the objective of the present study was to evaluate the effects of cage density on the performance and economic return (gain) of laying Italian quails.

\section{MATERIAL AND METHODS}

The experiment was carried out from April to October 2003 (24 weeks) at the poultry facilities from Fazenda Experimental Edgárdia, Faculdade de Medicina Veterinária e Zootecnia - UNESP, campus de Botucatu, Brazil. Female Italian quails $(n=264)$ were reared until 30 weeks of age and mean body weight of $280 \mathrm{~g}$ under identical management and feeding conditions. The birds were then housed in a $15 \mathrm{~m} \times 7$ $\mathrm{m}$ quail house equipped with 144 laying cages, from which 16 were used. The cages measured $96 \mathrm{~cm} \times 33$ $\mathrm{cm} \times 16 \mathrm{~cm}$ and were divided into three compartments. A randomized block design was used with four treatments (stocking densities of 12, 15, 18 and 21 birds/cage, corresponding to 264; $211 ; 176 ; 151 \mathrm{~cm}^{2} /$ quail) and 4 repetitions per treatment. Each cage compartment was equipped with a nipple drinker and a trough-type feeder. The quail house was equipped with curtains to assure optimal environmental conditions. The lighting program started at the second week after housing, with 14 hours of light per day and weekly increments of 30 min up to 17 hours per day. Birds were given feed and water ad libitum throughout the experimental period. One single corn soybean mealbased diet was used for all treatments, which was formulated according to the recommendations from NRC (1994) for laying quails. The percentage and calculated compositions of the diet are shown in Table 1. Feed was provided twice per day and any remaining food was weighed at week intervals. Eggs were weighed weekly and mean egg weight per parcel was calculated. The following parameters were evaluated: egg production, egg mass, feed intake, feed conversion per $\mathrm{kg}$ eggs, feed conversion per dozen eggs, mean egg weight, percentage of broken eggs and mortality.

The economic return (gain) was estimated considering a quail house with a capacity of 1,000 cages, and densities of 12,15, 18 or 21 birds per cage (264; 211, 176 and $151 \mathrm{~cm}^{2}$ per bird, respectively). The performance data obtained for each density in the experiment were used in the estimation. It was also computed the costs of the 28-day-old quails and expenses incurred related to investments, depreciation, labor, electricity and water, which were considered to be the same for all treatments.

\begin{tabular}{|c|c|}
\hline Ingredients & Percentage \\
\hline Corn & 56.33 \\
\hline Soybean Meal & 33.32 \\
\hline Soybean Oil & 2.860 \\
\hline Salt & 0.350 \\
\hline Limestone & 5.350 \\
\hline Bicalcium phosphate & 1.310 \\
\hline Vitamin and mineral supplement ${ }^{1}$ & 0.300 \\
\hline $\mathrm{DL}$ - Methionine & 0.139 \\
\hline Choline & 0.048 \\
\hline Total & 100.00 \\
\hline \multicolumn{2}{|l|}{ Nutrient levels } \\
\hline $\begin{array}{l}\text { Crude Protein (\%) } \\
\text { Metabolizable Energy (kcal/kg) }\end{array}$ & $\begin{array}{r}20.00 \\
2,900\end{array}$ \\
\hline Calcium (\%) & 2.500 \\
\hline Available phosphorus (\%) & 0.350 \\
\hline Methionine (\%) & 0.450 \\
\hline Methionine + Cystine (\%) & 0.760 \\
\hline Lysine (\%) & 1.070 \\
\hline \multicolumn{2}{|c|}{$\begin{array}{l}1 \text { - Levels provided per } \mathrm{kg} \text { of mineral supplement: } \mathrm{Cu}: 8,000 \mathrm{mg} \text {; Fe: } \\
50,000 \mathrm{mg} \text {; Mn: } 70,000 \mathrm{mg} \text {; } \mathrm{n} \text { : } 50,000 \mathrm{mg} \text {; I: } 1,200 \mathrm{mg} \text {; Se: } 200 \mathrm{mg} \text {. } \\
\text { Levels provided per } \mathrm{kg} \text { of vitamin supplement: vit. A: } 7,000,000 \mathrm{IU} \text {; } \\
\text { vit. D3: 2,000,000 IU; vit. E: } 5,000 \mathrm{mg} \text {; vit. K3: } 1,600 \mathrm{mg} \text {; vit. B2: } \\
\text { 3,000 mg; vit. B12: } 8,000 \mathrm{mcg} \text {; Niacin: } 20,000 \mathrm{mg} \text {; Pantothenic acid: } \\
\text { 5,000 mg; Antioxidant: } 15,000 \mathrm{mg} \text {. }\end{array}$} \\
\hline
\end{tabular}

Performance data were analyzed using the GLM procedure (General Linear Models) of SAS (SAS INSTITUTE, 1996). Different means were separated using the Tukey's test at $5 \%$ of significance.

\section{RESULTS AND DISCUSSION}

Results of egg weight, feed intake, laying rate, egg mass, percentage of broken eggs, mortality, and feed conversion (per egg mass and per dozen eggs) are shown in Table 2.

Stocking density had no effects ( $p>0.05$ ) on feed conversion per $\mathrm{kg}$ egg mass, percentage of broken eggs and mortality.

Feed intake was significantly affected by stocking density; in densities higher than $211 \mathrm{~cm}^{2}$ per bird, reduction in the floor area per bird decreased feed intake. It is probable that stress was increased because of the higher number of quails per cage and competition for food, as a consequence of smaller trough space per bird. Conversely, Waheda et al. (1999) reported that the feed intake of Japanese quails housed at densities of $175 \mathrm{~cm}^{2}$ per bird was higher than at densities of 150 and $200 \mathrm{~cm}^{2}$ per bird. Ahuja et al. (1992) showed that feed intake was not influenced by 


\begin{tabular}{|c|c|c|c|c|c|}
\hline \multirow[b]{2}{*}{ Variables } & \multicolumn{4}{|c|}{ Density ( $\mathrm{cm}^{2}$ per bird) } & \multirow[b]{2}{*}{ CV (\%) } \\
\hline & 264 & 211 & 176 & 151 & \\
\hline Feed intake ( $\mathrm{g} / \mathrm{bird} /$ day) & $43.33^{\mathrm{a}}$ & $40.75^{a}$ & $37.59^{b}$ & 34.92 & 4.27 \\
\hline Laying rate (\%) & $86.88^{a}$ & $90.20^{a}$ & $79.33^{b}$ & $79.23^{b}$ & 6.78 \\
\hline Mean egg weight ${ }^{1}(\mathrm{~g})$ & $13.55^{\mathrm{a}}$ & $13.30 \mathrm{ab}$ & $13.23 \mathrm{ab}$ & $12.88^{b}$ & 2.73 \\
\hline Egg mass ${ }^{1}(\mathrm{~g})$ & $12.34^{\mathrm{a}}$ & 11.99 a & $10.50^{b}$ & $10.21^{b}$ & 7.27 \\
\hline Feed conversion $(\mathrm{kg} / \mathrm{dz})$ & $0.57^{a}$ & $0.54^{b}$ & $0.57^{a}$ & $0.53^{b}$ & 5.68 \\
\hline Feed conversion $(\mathrm{kg} / \mathrm{kg})$ & 3.51 & 3.40 & 3.58 & 3.42 & 5.87 \\
\hline Broken eggs (\%) & 0.01 & 0.01 & 0.01 & 0.01 & 38.87 \\
\hline Mortality (\%) & 0.26 & 0.07 & 0.93 & 0.35 & 144.54 \\
\hline
\end{tabular}

Means followed by different letters in the row are significantly different by Tukey's test (5\%). 1 - Significant linear effect ( $p<0.05)$.

density when two housing systems (floor and cage) and two housing densities (100 and $125 \mathrm{~cm}^{2}$ per bird) were evaluated.

Quails housed at 211 and $264 \mathrm{~cm}^{2}$ per bird had higher laying rate when compared with the other treatments. The higher stress and the lower feed intake observed at the densities of 176 and $151 \mathrm{~cm}^{2}$ per bird have probably been responsible for the lower egg production in these groups. The results agree with previous results in Japanese quails that showed increasing egg production with decreasing stocking density when densities were 150, 180, 210 and 240 $\mathrm{cm}^{2}$ per bird (Nagarajan et al., 1991). Similarly, Tandrón et al. (1999) evaluated densities of 166.67; 133.33 and $111.11 \mathrm{~cm}^{2}$ per bird and reported higher laying rate at 166.67 and $133.33 \mathrm{~cm}^{2}$ per bird. On the other hand, Waheda et al. (1999) reported that there were no significant effects of housing density on production percentage for Japanese quails housed at 150, 175 and $200 \mathrm{~cm}^{2}$ per bird.

Egg weight was affected $(p<0.05)$ by cage stocking density. There was a linear reduction $(p<0.05)$ in egg weight with each increase in density from 264 to $151 \mathrm{~cm}^{2}$ per bird. Lower feed intake and higher energy expenses may be responsible for the reduced egg weight seen in birds housed in larger groups. Conversely, Ernst \& Coleman (1966), Bandyopadhyay \& Ahuja (1990), Nagarajan et al. (1991) and Garcia et al. (1998) evaluated different densities for Japanese quails and reported no effects on egg weight. The smaller size of Japanese quails compared to Italian quails might explain such disagreeing results.

Density significantly affected the produced egg mass, so that higher egg mass was seen at 264 and $211 \mathrm{~cm}^{2}$ per bird, and the produced egg mass decreased linearly with the increase in cage density (from 264 to $151 \mathrm{~cm}^{2}$ per bird). Since egg mass is obtained multiplying laying rate by egg weight and since these parameters have been affected by cage density, egg mass was directly influenced by these values. Similarly, a decrease in egg mass has been reported with increasing stocking densities for Japanese quails housed at $173.7 ; 152.0 ; 135.1$; 121.6 and $110.6 \mathrm{~cm}^{2}$ per bird (Garcia et al., 1998).

Birds housed at 151 and $211 \mathrm{~cm}^{2}$ per bird showed improved $(p<0.05)$ feed conversion per dozen eggs. These results corroborate previously reported results, but there are also disagreeing results. Tandrón et al. (1999) evaluated densities of 166.67; 133.33 and $111.11 \mathrm{~cm}^{2}$ per bird and reported improved feed conversion at densities of 166.67 and $133.33 \mathrm{~cm}^{2}$. On the other hand, Nagarajan et al. (1991) housed Japanese quails at 150,180, 210 and $240 \mathrm{~cm}^{2}$ per bird and concluded that feed conversion was improved with decreasing housing density. Finally, Waheda et al. (1999) concluded that feed conversion was not influenced by stocking densities of 150, 175 and 200 $\mathrm{cm}^{2}$ per bird in an experiment using Japanese quails.

Table 3 shows that there was better gain per bird per day at a density of $211 \mathrm{~cm}^{2}$ because of better laying rate, although the gain per quail house $(J)$ was better at a density of $151 \mathrm{~cm}^{2} /$ bird. It is possible that the greater number of birds housed in this density might have compensated for the smaller egg production.

\section{CONCLUSIONS}

Smaller floor space per bird resulted in a linear decrease in egg weight and egg mass. Feed intake and egg production were lower at densities of 176 and $151 \mathrm{~cm}^{2}$ per bird.

The smaller density $\left(151 \mathrm{~cm}^{2}\right.$ per bird or 21 birds per cage) have resulted the best gain per quail house per day. Nevertheless, the best gain per bird per day was seen at densities of $211 \mathrm{~cm}^{2}$ per bird (15 quails per cage), and it is thus recommended as an adequate stocking density for Italian quails. 
Table 3 - Gain estimated for a quail house with 1,000 cages

Parameters

\begin{tabular}{rrr} 
& \multicolumn{2}{c}{ Density $\left(\mathrm{cm}^{2} /\right.$ bird $)$} \\
\hline 264 & 211 & 176
\end{tabular}

151

(A) Birds per quail house (L)

(B) Feed intake (g/bird/day)

12,000

15,000

(C) Total feed intake (kg/quail house/day) $(C)=(A) \times(B)$

(D) Number of eggs produced per bird per day

43.33

(E) Total eggs produced (eggs/quail house/day) $(E)=(A) \times(D) \quad 10.426$

(F) Total feed cost (feed/quail house/day) $(R \$)(F)=(C) x(M)$

10.426

(G) Total egg income (eggs/quail house/day) $(\mathrm{R} \$)(\mathrm{G})=((\mathrm{E}) / 30) \times(\mathrm{N}) \quad 851.46$

$(H)$ Initial bird cost per quail house $(R \$)(H)=(A) \times(O)$

(I) Initial bird cost per day $(R \$)(I)=(H) /(P)$

(J) Gain per quail house/day $(R \$)(J)=(\mathrm{G})-(\mathrm{F})-(\mathrm{I})$

(K) Gain per bird/day $(R \$)(K)=(J) /(A)$

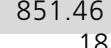

18
9.31

516.17

Considering: (L) Quail house with 1,000 cages. (M) Feed cost: $R \$ 0.55 / \mathrm{kg}$. (N) Carton with 30 eggs: $R \$ 2.45$. period: $R \$ 1.50 /$ bird. (P) Production period: 365 days.

\section{REFERENCES}

Ahuja SD, Bandyopadhyay UK, Kundu A, Gopal R. Influence of stocking density and system of housing on growth characters in Japanese quail. Indian Journal of Poultry Science 1992; 27(4):193197.

Anderson KE, Adams AW, Effects of rearing density and feeder and waterer spaces on the productivity and fearful behavior of layers. Poultry Science 1992; 71(1):53-58.

Bandyopadhyay UK, Ahuja SD. Effect of cage density on some of the egg quality traits in Japanese quail. Indian Journal of Poultry Science 1990; 25(3):59-162.

Ernst RA, Coleman TM. The influence of floor space on growth, egg production, fertility and hatchability of Coturnix coturnix japonica. Poultry Science 1966; 45:437-440.

Garcia EA, Mendes AA, Gonzales E, Silva ABP, Saldanha ESPB. Desempenho produtivo e econômico de codornas poedeiras alojadas sob diferentes taxas de lotação da gaiola. Boletim Indústria Animal, 1998;55-185-188.

Nagarajan S, Narahar LD, Jayaprasad IA, Ihyagarajan D Influence of stocking density and layer age on production traits and egg quality in Japanese quail. British Poultry Science 1991; 32(3):243-248.

NRC-National Research Council Nutrient requirements of poultry. $9^{\text {th }}$ ed. Washington: National Academy Press, 1994. 156p.

SAS Institute. SASâ User's Guide: Statistics. Cary; 1996.

Tandrón E, Polanco G, Perez A, Pina Z. Efecto de la densidad de alojamiento y la relación hembra macho sobre los indicadores productivos en la codorniz japonesa (Coturnix coturnix japonica). Revista Cubana de Ciencia avícola 1999; 23:23-30.

Waheda P, Rabba MG, Howlider MAR., Waid MA. Interaction of group size and stocking density on egg production performance of Japanese quail. Bangladesh Veterinarian 1999; 16(1):29-33. 